\title{
[ Power over Bare Life: The War on Terror in Post-9/11 British and American War and Political Drama ]
}

\section{Michala Rusňáková}

University of Jan Evangelista Purkyně, Ústí nad Labem

[Abstract] The article discusses the concept of sovereign power over individuals presented in three contemporary British and American theatre plays, specifically in Guantanamo: Honor Bound to Defend Freedom by Vera Brittain and Gillian Slovo, Frances Ya-Chu Cowhig's Lidless and Yussef El Guindi's Back of the Throat. The focus of the paper is on the representation of suspected terrorists, their imprisonment, abuse and torture. The plays are examined from the perspective of Girard's concept of scapegoat, Foucault's biopolitics and torture, and Agamben's sovereign power over bare life and state of exception, in order to show mechanisms applied by the US government to deny the suspects of their freedom and human rights.

[Keywords] Brittain and Slovo; Ya-Chu Cowhig; El Guindi; post 9/11 war drama; Guantanamo; detainees; torture; Foucault; Agamben; Girard 


\section{[1] Introduction}

The number of British and American war plays written during most of the 20th century is highly disproportionate to the importance of the theme. In the United Kingdom, the crucial reasons were censorship and the alleged unreadiness of the audience to face the atrocities of war. In the United States, war plays have been in danger of being perceived as unpatriotic and thus unacceptable for the American audience. This tendency slowly began to alter (at least in the United Kingdom) with the "revolutionary sixties", the rise of documentary drama and the emergence of in-yer-face theatre. However, as Boll states, "the bibliographical record on this subject remains rather thin" and "critics only recently recognised the continuous representation of war and conflict on stage as a reason enough to identify 'war and conflict plays' as a literary genre in its own right” (3).

The relatively recent recognition of war drama as a stand-alone genre is, in fact, related to the rise of New War Plays. As the term implies, these are plays focused on the wars that have taken place in the last three decades. Nevertheless, the New Wars are called new because they differ greatly in many aspects from the previous ones. As Kaldor, who first coined the term, explains, starting with the Gulf War a "new type of organized violence developed", violence of a political nature which "involve[s] a blurring of the distinction between war, [...] organized crime [...] and large-scale violations of human rights" (1-2). The New Wars theory was consequently applied by Boll in the description of the New War Plays. According to her, "the New War Plays examine the roots of human aggression and the wars that result by exploring contemporary society's position towards what is taboo and 'sacred' [...and] portray the state of exception as the norm in times of war" (9). The three plays analyzed in this paper correspond with this definition as they focus on the War on Terror, i.e. the ongoing global conflict that the United States launched soon after the 9/11 attacks. These plays, however, are unique because at their center are suspected terrorists. More specifically, in Back of the Throat by Yussef El Guindi the main character Khaled is interrogated and abused in his flat by two agents because of his presumed cooperation with Asfoor, a dead terrorist. The other two plays, Guantanamo: Honor Bound to Defend Freedom (hereafter Guantanamo) by Victoria Brittain and Gillian Slovo and Lidless by Francis Ya-Chu Cowhig, concentrate on some of the suspected terrorists that have been captured by the US army, labeled as illegal combatants, and imprisoned and tortured in the Guantanamo Bay detention camp.

The three plays were selected specifically because they give voice to those who are unheard, visibility to the unseen, and attention to the ignored. In fact, Guantanamo was "one of the earliest theatrical responses" to the stories recounted by the first released British detainees (de Waal 181) and it "appeared in advance of a widespread public understanding that Guantanamo was both an illegal detention camp and that it permitted the use of torture" (Colleran 9). Through their play, Brittain and Slovo therefore helped to expose the atrocities to the public and campaigned for the release of the detainees. It is worth mentioning that the key message of the play is intensified by the use of authentic material, such as interviews, letters, and public speeches, and that the play was 
premiered at London's Tricycle Theatre, which "over the last 15 years [... has] been at the epicenter of the revival in documentary performance in the UK" (Megson 195). Thus, unlike the other two plays analyzed in this paper, Guantanamo is classified as documentary or verbatim drama.

This paper aims to examine how the suspects are given voice in these plays, how the authors described who these men are and how they ended up as suspects of terrorism. This topic is approached through Girard's concept of scapegoat. Furthermore, Agamben's theory of bare life is used to analyze how the characters were stripped of their human rights. Last but not least, the question of how a supposedly democratic country in the $21^{\text {st }}$ century can capture, illegally imprison, and torture citizens of their own as well as other nations will be addressed via Foucault's perspective on biopolitics and torture, taking into consideration Agamben's concept of sovereign power and state of exception.

\section{[2] Scapegoating}

Since 2002, about 780 men have been detained at the military prison in Guantanamo Bay, while the overall number of those that were interrogated in other places remains unknown. In the verbatim play Guantanamo, these men are represented by four British prisoners - Bisher al-Rawi, Jamal Al-Harith, Moazzam Begg, and Ruhel Ahmed - and in Lidless by one of the main characters Bashir. Back of the Throat differs from the previous two plays as Khaled is not imprisoned. He is interrogated and abused by agents in his own home somewhere in the United States. Although Colleran describes the capture of prisoners in the first act of Guantanamo as random (174), the plays encourage a different perspective.

According to René Girard, in times of crisis human relationships fall apart and people stand in opposition; thus, they look for a cause of the crisis either in the whole society or in a specific group of people (12-56). Similarly, Clive Stafford Smith, a character in Guantanamo, explains that the mechanism of hatred of the detainees reminds him of the hatred people feel towards people on death row: "It's all about hatred. About how you get a huge group of people to hate a small group of people [...] and blame them all for the problems in the world" (Brittain and Slovo 33). In Back of the Throat Bartlett, one of the agents abusing Khaled, claims:

One more thing: at no time should you think this is an ethnic thing. Your ethnicity has nothing to do with it other than the fact that your background happens to be the place where most of this crap is coming from. So naturally the focus is going to be on you. It's not profiling, it's deduction. You're a Muslim and an Arab. Those are the bad asses currently making life a living hell, and so we'll gravitate towards you and your ilk until other bad asses from other races make a nuisance of themselves. Right? Yesterday the Irish and the Poles, today it's you. Tomorrow it might be the Dutch. (El Guindi 151) 
Bartlett articulates the prejudice and suspicion under which Muslims and/or Arabs have lived since 9/11. Despite the obvious contradiction in his statements, it is true that ethnicity or religious affiliation cannot, due to sheer numbers, possibly be the only criterion. Nevertheless, it is an important one. According to Girard, scapegoats are often foreigners or ethnic or religious minorities because they differ from the majority and they are seen as strange, abnormal, with difficulties adapting (12-20). The assumed terrorists imprisoned in Guantanamo are mainly Muslims that were captured in Afghanistan or Pakistan, where the government of the United States offered significant financial rewards. They included citizens of 49 different countries, more than half of them from countries other than Afghanistan or Pakistan (data obtained from The New York Times online project The Guantánamo Docket, Scheinkman, et al). In Guantanamo, it is Moazamm Begg, a British citizen, who went to Afghanistan with his wife and children to open an elementary school there. When the Americans bombarded Kabul he fled with his whole family to Islamabad, where he was arrested in front of his children by two Americans assisted by two Pakistanis. Jamal al-Harith, another character in the play, who went to Pakistan on tableeg, was handed over to the Taliban and then by the new government to American soldiers. Ruhel Ahmed, also a British citizen, was captured in Afghanistan. Last but not least, Bisher al-Rawi was arrested in Gambia. His case is especially interesting because he was arrested together with his brother Wahab al-Rawi, who was released after 27 days even though they might have been regarded with the same suspicion. Mark Jennings, the family lawyer, casts light on the situation when he states that "the only difference between [the two brothers] is that Wahab al-Rawi has British citizenship and Bisher doesn't" (El Guindi 17). Bisher is, in fact, an Iraqi citizen, which is apparently more suspect in Gambia. These men are, therefore, foreigners not only from the American perspective but also from the perspective of those who sold them to the US government.

In Guantanamo it often comes to Jamal's mind that he does not belong there because he is from Manchester (Brittain and Slovo 34). In Back of the Throat, Yussef El Guindi elaborates on this paradox, in which the majority point of view is accepted by the members of minority, in detail. The main character of his play, Khaled, understands that he meets the criteria of persecution, feels the urgency to explain and justify himself, and repeatedly claims that he is not religious, he does not speak Arabic, he is a citizen, the United States is his country as well, and his interests are the same as those of the majority (El Guindi 137-148).

Other criteria for persecution are, according to Girard, accusations of "violent crimes which choose as object those people whom it is most criminal to attack [...] Then there are sexual crimes: rape, incest, bestiality. The ones most frequently invoked transgress the taboos that are considered the strictest in the society in question" (15). These accusations can be also found in the two plays. In Guantanamo, the character Donald Rumsfeld, the Secretary of Defense, proudly declares in his public speech that the government succeeded in the apprehension of a large number of people that were trained to "kill innocent people - [...] not other soldiers" (Brittain and Slovo 24). In Back of the Throat, Bartlett accuses Khaled of zoophilia, because he found in his flat a porn magazine with a picture 
of naked women leaning on a cow, and later of pedophilia without any apparent reason (El Guindi 148). Within their interaction, the accusations are obviously used as a tool for humiliation and the establishment of Bartlett's superiority and power. To the audience, however, they communicate how the mechanism of persecution works. Guantanamo forces the reader to face their own tendencies to yield to stereotypes of persecution and constantly consider the probability of the innocence or guilt of individual characters. For example, when Mr. Begg describes his son Moazzam's life before the arrest by explaining how he decided to open a religious books and clothing store in England or how he decided to open a school in Afghanistan, it may be difficult for readers to resist the idea that there might be, after all, something suspicious in Moazzam's behavior. Acquaintance with other detainees is constructed in the same way. The brothers Bisher and Wahab admit they were friends with Abu Qatada, who at the time of the publication of the play was repeatedly charged and detained in the UK for collaborating with a terrorist organization and was acquitted ten years later, in 2014 in Amman (BBC).

Proving the suspects' membership of a terrorist organization is not, in fact, crucial, as Girard demonstrates using the example of Jewish doctors, who were accused of "poisoning, a crime that deprives the accused of any legal protection just as bluntly as any accusation directly involving magic. Poisoning is so easy to conceal especially for a doctor that it is impossible to prove the crime and therefore there is no need to prove it" (47). A similar type of reasoning is often applied to detainees held in Guantanamo, but also elsewhere, as in the notorious Abu Ghraib. In Guantanamo, this practice is demonstrated in the following exchange at a press conference:

NEWSPAPERMAN 1. But have you determined [the detainees'] status individually, on an individual?

RUMSFELD. Yes, indeed, individually.

NEWSPAPERMAN 1. So you know which are al Qaeda and which are Taliban?

RUMSFELD. 'Determined' is a tough word. We have determined as much as one can determine when you're dealing with people who may or may not tell the truth. (Brittain and Slovo 24-25)

Terrorist organizations are said to be complex and sophisticated networks in remote territories whose members live and move around the world. These members have multiple identities and apparently, as explained by Mr. Rumsfeld, once they are captured and interrogated they may even lie; it is thus not necessary to prove their membership of the network because it would be too difficult, if not impossible. Another frequently used argument that Girard also mentions is the belief that it is not possible for the suspects to be innocent because no one would treat innocent people like this (47). Carl, the second agent in Back of the Throat, articulates this directly in a conversation with Khaled when he asks: "If you were innocent, why would I have kicked you?" (El Guindi 171). 


\section{[3] Reducing to bare life}

In the 21st century, scapegoating does not lead to ritual sacrifice that would reestablish understanding and a sense of belonging in society as it did in the past. Nevertheless, today's society is willing to accept a sacrifice as significant: the scapegoats' freedom and human rights. While a scapegoat, as Boll states, is "the person who has become a taboo" (65), or more precisely, who has become a social taboo, homo sacer is "a political taboo of our society" ( 9 emphasis added). The concept of homo sacer was introduced by Giorgio Agamben, who elaborates on Foucault's biopolitics and claims that at the end of the 17th century, European democracy "placed at the center of its battle against absolutism not bios, the qualified life of the citizen, but zoe - the bare, anonymous life that is as such taken into the sovereign ban" (Agamben, Homo Sacer: Sovereign Power and Bare Life 123). Agamben describes "two extreme limits of the order, the sovereign and homo sacer" which are correlative and are distinct "from both the natural order and the regular juridical order" (Homo Sacer: Sovereign Power and Bare Life 87). Homo sacer is an outcast of society, simultaneously sacred and damned, as he cannot be sacrificed and, at the same time, killing him or perpetrating violence on him is not punished. The sovereign, by contrast, has the almighty power to create a state of exception "that binds and, at the same time, abandons the living being to law" (Agamben, State of Exception 1). It is the sovereign that places the homines sacri in the state of exception.

According to Boll, "the New War Plays portray people in various stages of losing or having lost their status of bios, having been reduced to bare life in form of the homo sacer" (59). Moreover, one of the crucial messages of Guantanamo is the revelation that such a reduction to bare life was a "decision made at the highest levels" (Brittain 216). Her play, in addition, exposes the mechanisms that enable the US government to imprison and torture almost 800 men of different citizenships in a secluded camp despite the Geneva Conventions; or, as Hesford expresses it, the play shows "the ethical implications of designating the detainees as 'enemy combatants', instead of prisoners of war protected by international laws governing their treatment" (36). In the play two approaches to this issue are taken, i.e. demonstration and explanation. Two pairs of characters are successively brought to the stage - government representatives and legal experts. In their speeches, the Vice President Dick Cheney and the Secretary of Defense Donald Rumsfeld declare that these prisoners are not considered prisoners of war but they are so-called unlawful combatants. While the two government representatives demonstrate the mechanism, the two lawyers explain it. First, Lord Justice Johan Steyn points out that President Bush had already called the detainees killers at the beginning of their imprisonment before any steps, such as an interrogation or a criminal trial, were taken. Later Gareth Peirce, a lawyer, describes some of the rhetorical devices that the US government used to persuade the public of the validity of the "unlawful combatants" label:

There are a number of concepts which are deliberately confused by the American administration. It seized people for purposes that are clearly the obtaining of in- 
formation and having seized those people, it transferred them to a place which it believed would be beyond the reach of courts in America. It claimed that it had seized people on the battlefield, there were frequent references to capture on battlefield, and then, having presented it to the world in this way, found itself stuck with the immediate response, well if these are prisoners of war, they are entitled to give name, rank and number and no more, and they deserve to be treated as the Geneva Convention dictates and not to be made the subject of interrogation. So having at first grabbed the nearest label, finding that it meant that were international treaty obligations to provide prisoners of war with rights, the regime very quickly had redefined what it had, and therefore it said these were unlawful combatants who were not wearing uniform and were not conforming to the norms of warfare. (Brittain and Slovo 25-26)

In this manner they were stripped of all human rights and reduced to bare life. Thus, they stand outside the legal system not only of the United States but of law as such.

In Lidless the issue of bare life is approached in much subtler and more concealed manner. For instance, in the following exchange between Bashir, a former Guantanamo prisoner, and Rhiannon, a young girl, a parallel to reduction of the prisoners to homo sacer can be drawn:

RHIANNON. They ask at the store if the animal's going to be a pet. If you say yes, you sign a form that says you understand your pet is a living thing that needs food and water, blah, blah, blah. If you don't sign it, it's not a pet.

BASHIR. So the animal's quality of life depends on whether you classify it pet or a non-pet?

RHIANNON. There's no such thing as non-pets. They're called feeders. (Cowhig 30)

Similar to the detainees, an animal's conditions of its life, even its right to live, is decided based on the categorization declared by the person in charge, the sovereign. The animal is given the status of a living thing only when the customer designates it a pet. The classification as pet or feeder evokes the political frames described by Butler, who states that "certain lives are perceived as lives while others, though apparently living, fail to assume perceptual form as such" (24).

Another thought-provoking remark is later made by Bashir again, this time in his conversation with Alice, his former interrogator in Guantanamo, who confesses that her only recollection from the time in the camp is of iguanas.

ALICE. Iguanas. That's all I remember about Gitmo. Iguanas crossing the road. I was so scared of hitting one and having to pay a fucking ten thousand dollar fine.

BASHIR. The iguanas were lucky. The Endangered Species Act was enforced. (El Guindi 43) 
It is suitable for Bashir to be the one who connects the dots and shows the bigger picture to the audience, as he is the one who has the personal experience. He is the one who was submitted to complete control at the hands of the sovereign's mercy. Unfortunately, Alice seems not to be able to grasp the meaning of his gentle remark. The irony of iguanas being protected and their lives being literally given a price by the US government, the same government that claims the imprisoned people stand outside any law, have no rights and their lives have no value, is lost on her.

El Guindi's approach to the reduction to bare life differs significantly from the above-mentioned writers. In his play Back of the Throat, he uses an increasing feeling of threat in the way Harold Pinter does in his comedies of menace, picturing the power of the sovereign over bare life and the incursion on individual human rights within the microcosm of Khaled's flat. Here many hierarchical layers are omitted, and Bartlett and Carl, the two agents, operate as a contemporary sovereign with absolute power over the homo sacer, Khaled. First, they try to declare that they are in charge. When Khaled repetitively states that he has rights and refuses to continue in the conversation without the presence of his lawyer, Bartlett answers "no you don't, you've been misinformed" and that the only right that Khaled has "is the right to cooperate with [the] intelligence and do the right thing" (El Guindi 148). When Khaled does not react according to their wishes, Carl decides to reestablish their authority with physical violence. From Carl's viewpoint, Khaled "thinks there's some script [they]'re supposed to follow and that will protect him" and so he suggests bringing "the full weight of [their] authority to bear on him. With the aim of making him adjust his expectation as to what options are available to him" (El Guindi 170). By the end of the play the distribution of power is clear even to Khaled, as he was physically attacked couple of times and eventually stripped when Carl and Bartlett decided to see whether he has a tattoo on his penis.

\section{[4] Torture}

In his Discipline and Punish: The Birth of the Prison, Michel Foucault describes the turning-point in the punishment of prisoners that took place at the end of the $18^{\text {th }}$ century in Western European countries, specifically France and England. He explains how the public punishment, torture and execution of prisoners became an undesirable phenomenon. Despite a certain irregularity in the process, it can be stated that within several decades torture disappeared not only from public spaces but in general, ceasing to function as a demonstration of judicial power (Foucault 3-32). A century and a half later, the United Nations General Assembly ratified the Convention against Torture and Other Cruel, Inhuman or Degrading Treatment or Punishment which was subsequently signed by 167 countries around the world. Regardless of the convention, torture perpetrated on citizens of their own as well as other countries still occurs not only in countries with totalitarian regimes but also in countries that are generally considered democratic guardians of freedom and human rights. Specifically, in the United States of America, where President Bush and his administration established for this purpose a detention camp at Guantanamo Bay 
and declared it a place beyond law or order and the protection of the courts, a place labeled by many a legal black hole or as de Wall expresses it, "the fundamental biopolitical paradigm" (182). As Hughes states, "a state of exception is produced by means of a performance - a declaration" (4-5) and "a camp is where the state of exception is given form" (126). Originally, Agamben used the state of exception concept to describe the establishment of Nazi concentration camps. The Guantanamo Bay detention camp, however, also answers his characterization: "in the camp, the state of exception, which was essentially a temporary suspension of the rule of law on the basis of a factual state of danger, is now given a permanent spatial arrangement, which as such nevertheless remains outside the normal order" (Agamben, State of Exception 168).

In Guantanamo, the lawlessness is openly admitted by American soldiers who, similarly to Bartlett and Carl mentioned above, claim "there's no law here, it does not apply" (Brittain and Slovo 35). The treatment of detainees is depicted in detail. In fact, there are cages on the stage with actors trapped in them. They never speak and do not leave when the play is over. In this way, their silenced voice as well as the endlessness of their imprisonment is depicted. It is important to mention, however, that their torture is not directly shown to the audience. The fact that during their stay in Guantanamo, they are exposed to attacks of spiders, scorpions, and mice, beaten and kicked during interrogations, held in chains in so-called stress positions, starved or fed the same food for years, held in solitary confinement, denied medical help and legal representation, never informed why they are held or for how long or what they are accused of, or that many of them, of course, suffer from health and/or mental issues for years even after the release - all these things are described by members of their families and lawyers. While Hesford claims that "the characters' stories are presented to the audience in long, isolated stretches of verbatim readings from testimonies and letters [...that] accumulate and begin to create a polyphonic subjectivity" (35), it can be also considered a useful method in avoiding audience voyeurism; as Boll states, trauma should be displayed "in an instance of haunting" as it "seems to be an adequate way to negotiate the question of the ethics of representing what is, essentially, unrepresentable" (96).

The torture is, in fact, not presented directly in Lidless either. Here, the temporal distance is much more significant, as most of the play takes place about fifteen years after Bashir was imprisoned. Thus, the interrogations appear mainly in the reminiscences of the two main characters, Bashir and Alice. At the beginning of the play, Alice introduces a new technique of interrogation. As Friedman explains, female soldiers are used as a "weapon of war" (607) and "sexuality [...] an intelligence tool" (606). The strategy that was specifically designed by the American administration to force Muslim detainees to cooperate is called the "Invasion of Space by a Female". Alice explains to Riva, her friend, the reason: "these guys, with their fasting and praying - they can shut you out. Go anywhere in their heads. That bullshit 'bout waterboarding, the inhumanity of it - it's missing the point. These guys believe there's a special place in heaven, with extra virgins and shit, for people who die by drowning. All you do when you waterboard is give 'em extra credit for the ever after. We gotta make 'em stop believing. Make it matter whether they 
live or die. What we gotta do is, damn their soul" (Cowhig 8). Riva, an Iraqi doctor, warns her not to bruise the detainee but at the same time advises her: "tell him you're menstruating. Rub something red onto your hands. If he thinks you're on your period - he'll go crazy" (Cowhig 9); she thus takes the new method to a whole other level. In the course of the play, it becomes clear that Alice raped Bashir, which leads to horrible consequences for both of them as well as for the members of their families.

Guantanamo, of course, is not the only place where a state of exception is materialized. As explicated in Guantanamo by Clive Stafford Smith, who runs a legal charity representing Guantanamo Bay detainees, "none of [the people that they think are] real bad dudes are in Guantanamo Bay, because the American Government would never put them there while there is a possibility that we'll get jurisdiction to litigate to get them out of there. So all of them are in Bagram air force and places like that" (Brittain and Slovo 26). Furthermore, the practice called "outsourcing torture" (Mayer) is described by another character, Gareth Peirce. She states there are "700 in Guantanamo, [there are] however many thousands around the world, distributed in places where Guantanamo would probably look quite humane. And there is a process of shipping people for instance to Egypt, where you know they'll be tortured. [You] torture something out of them, then get them back to Guantanamo. [It's] a grotesque international redistribution" (Brittain and Slovo 27). In this manner, the prisoners are excluded from the American judicial legal system not only on the abstract or theoretical level, but also on the practical and physical one.

The administration of torture portrayed in these plays takes the audience centuries back to what Peirce in Guantanamo calls "medieval horror" (Brittain and Slovo 41). The reversion of the practice, however, is much more significant. Foucault explains that the mixture of investigation and punishment is tightly related to a concept of guilt not seen in a binary perspective as guilty vs. innocent but rather as a scale. The arrested person is already perceived as guilty because he or she is suspected of doing something (41-42). Such a perspective on guilt, in which it is not the plaintiff's task to prove someone is guilty but to what degree, moreover using any means necessary, not only wrecks the concept of the presumption of innocence but also causes a paradigm shift that can have crucial implications in everyone's life. As Greg Powell, a lawyer of one of the prisoners, describes in Guantanamo:

if you fall under suspicion, you can be subject to a special tribunal, you can be made subject to special measures if you like, and you could be electronically tagged, you could be denied access to certain people, you could be put in a certain geographical area, you could be limited where you go. All those features that I just described can be made applicable to you, so effectively you have this fantastic level of social control by some individuals inside the community. [...] You can't start to think like this unless something like Guantanamo exists. In a way is an experiment but it leads you on into a much more controlling social control criminal justice system. (Brittain and Slovo 42) 


\section{[5] Conclusion}

The main aim of this paper was to examine how those who are usually not heard are given voice in contemporary war and political theatre plays. Specifically, it focused on the people suspected of terrorism and the ways in which they have been treated by the government of the United States and its political and military representatives in the course of the war on terror. The analysis of the three selected plays shows that these people are often persecuted because of their ethnicity and/or religious affiliation. In addition, the characters also meet the criteria of persecution defined by Girard in Scapegoating, as they are foreigners in the countries from which they were kidnapped and sent to Guantanamo, they are accused of attacking the most innocent members of the society, i.e. civilians, and in the case of Khaled in Back of the Throat also of sexual perversion. The plays show that the prisoners are deprived of their freedom and human rights, reduced to bare life and placed in a state of exception outside any law. The dehumanization is executed by the sovereign, the US administration, simply by classifying them as unlawful combatants. The plays were therefore analyzed through the perspective of Giorgio Agamben's concept of homo sacer, sovereign and state of exception. Guantanamo explicitly comments, through the monologues of some characters, on the practices and rhetorical devices applied by the US government. Back of the Throat depicts two agents that become a contemporary sovereign and make their suspect Khaled understand that he has no rights. In Lidless, the reduction to homo sacer is pointed out by Bashir in the comparison of the alleged worthlessness of prisoners' lives and the importance and value of iguanas protected by US law. Finally, the paper focused on the representation of torture in the plays, drawing on Foucault's views. While Khaled in Back of the Throat is physically attacked and violently stripped on the stage, the other two plays do not directly show the torture. Guantanamo uses the testimonies of the detainees and their letters to speak instead. Similarly, in Lidless, the torture is also mainly discussed, especially in the conversations between Bashir, the former detainee, and Alice, his former interrogator. Moreover, during the play it is revealed that Alice in fact raped Bashir. The two latter plays also show that the torture practices were specifically adjusted to the detainees' cultural and religious beliefs. In this way, the plays help the audience to reconsider their perspective on and perception of war and those who are, voluntarily or not, involved in it, and warn them about the consequences such government practices might have for them.

\section{[Bibliography]}

Agamben, Giorgio. Homo Sacer: Sovereign Power and Bare Life. Stanford: Stanford University Press, 1998.

---. State of Exception. Chicago: University of Chicago Press, 2005.

BBC News. "Abu Qatada Cleared of Terror Charges.” BBC News, 24 Sept. 2014, www.bbc. com/news/world-29340656. Accessed 3 Jan. 2020.

Boll, Julia. The New War Plays: From Kane to Harris. London: Palgrave Macmillan, 2013. 
Brittain, Victoria. "Guantanamo: A Feminist Perspective on U. S. Human Rights Violations.” Meridians. 6.2 (2006): 209-219. JSTOR, www.jstor.org/stable/40338709. Accessed 2 Jan. 2020.

Brittain, Victoria, and Gillian Slovo. Guantanamo: Honor Bound to Defend Freedom. E-book, London: Oberon Books, 2005.

Butler, Judith. Frames of War: When Is Life Grievable?. London: Verso, 2009.

Colleran, Jeanne. Theatre and War: Theatrical Responses since 1991. New York: Palgrave Macmillan, 2012.

Cowhig, Frances Ya-Chu. Lidless. New Haven: Yale University Press, 2010.

De Waal, Ariane. Theatre on Terror: Subject Position in British Drama. Berlin and Boston: De Gruyter, 2017.

El Guindi, Yussef. "Back of the Throat." American Political Plays after 9/11. Ed. Allan Havis, Carbondale: Southern Illinois University Press, 2010. 137-186.

Foucault, Michel. Discipline and Punish: The Birth of the Prison. London: Penguin Books, 1977.

Friedman, Sharon. "The Gendered Terrain in Contemporary Theatre of War by Women”. Theatre Journal. 62.4 (2010): 593-610. JSTOR, www.jstor.org/stable/41000802. Accessed 4 Jan. 2020.

Girard, René. The Scapegoat. Baltimore: Johns Hopkins University Press, 1986.

Hesford, Wendy S. “Staging Terror.” TDR (1998-). 50.3 (2006): 29-41. JSTOR, www.jstor. org/stable/4492693. Accessed 2 Jan. 2020.

Hughes, Jenny. Performance in a Time of Terror: Critical Mimesis and the Age of Uncertainty. Manchester: Manchester University Press, 2011.

Kaldor, Mary. New and Old Wars. Stanford: Stanford University Press, 2012.

Mayer, Jane. “Outsourcing Torture.” The New Yorker, 7 Feb. 2005, https://www.newyorker.com/magazine/2005/02/14/outsourcing-torture. Accessed 4 Jan. 2020.

Megson, Chris. "Half the Picture: 'A Certain Frisson' at the Tricycle Theatre.” Get Real: Documentary Theatre Past and Present. Eds. Alison Forsyth and Chris Megson. Basingstoke: Palgrave Macmillan, UK, 2009. 195-208.

Scheinkman, Andrei, et al. The Guantanamo Docket. The New York Times, https://www. nytimes.com/interactive/projects/guantanamo. Accessed 2 Jan. 2020.

\author{
[Address] \\ University of Jan Evangelista Purkyně \\ Department of English \\ Faculty of Education \\ České mládeže 360/8 \\ 40001 Ústí nad Labem \\ michala.rusnakova@ujep.cz
}


Michala Rusňáková is a teacher at Jan Evangelista Purkyně University in Ústí nad Labem. She received a Master's degree in English Language Teaching in 2016 and is currently working towards a PhD in American Literature. At Jan Evangelista Purkyně University, she teaches British literature and didactics of literature. Her research interests include contemporary British and American drama, political and war drama, and Arab-American literature. 